\title{
IMPROVED BURNING DOWN PROTECTION SYSTEM OF INDUSTRIAL ELECTRON ACCELERATORS OUTLET WINDOW FOIL
}

\author{
S.O. Bandurov ${ }^{1}$, R.S. Lozhkin', G.O. Shishkin ${ }^{3}$ \\ ${ }^{1}$ "Azov Cable Company" LLC, Berdyansk, Ukraine \\ E-mail: science.azovcablecompany@gmail.com; \\ ${ }^{2}$ National Technical University "Kharkiv Polytechnic Institute", Kharkiv, Ukraine \\ E-mail: Ukraine, rslozhkin@gmail.com; \\ ${ }^{3}$ Berdyansk State Pedagogical University, Berdyansk, Ukraine \\ E-mail: Oblast', Ukraine, ur3qugs@gmail.com
}

\begin{abstract}
The results of the industrial electron accelerators protection system deficiencies analysis in the event of emergency conditions are given and the ways to improve it are suggested in the article. The principle of the protection system functional scheme operation and its main characteristics are described. The proposed protection system on current windings of horizontal and vertical sweeps can be applied in industrial accelerators of the ELV-1 series.
\end{abstract}

PACS: 29.20.-c. 41.75Fr

\section{INTRODUCTION}

In modern industry's technological processes electron accelerators are increasingly used for radiation treatment of polymers, contaminated water purification, grain desinsection, processing of metal and other solids to improve their qualitative properties [1].

The most widespread in industry, among electron accelerators, linear pulse accelerators and transformer accelerators of DLS type, developed and manufactured at the Budker Institute of Nuclear Physics [2,3] have become. It should be noted that works on the development of new series of this type accelerators, aimed to solve the problems of their technical indicators increasing are constantly carried out by the institute scientists $[4,5]$.

In the industry transformer electron accelerators of direct-on-line starting type - ELV [6] obtained more extensive demand. The experience in the operation one of the first in the range of such type accelerators - electron accelerator series ELV-1 showed that nowadays there is the need for their improvement and bringing to the technical level and requirements of modern production.

The work purpose is to improve the protection system on currents in the coils of horizontal and vertical sweeps from titanium foil burning in industrial transformer-type DLS accelerator series ELV-1 in terms of improving equipment protection.

\section{PROBLEM STATEMENT}

One of the drawbacks of the ELV-1 series electron accelerator protection systems used in the industry is the unimproved sweep protection system of 50 and $1075 \mathrm{~Hz}$. Electric power supply interruption by the unit of the horizontal and vertical coils sweeps can lead to burning of the accelerator outlet window titanium foil by electron flow.

In order to prevent the burning of the outlet window foil by an electron beam the manufacturer has developed a protection block for the accelerators of this series. The unit consists of foil protection system on horizontal sweep $50 \mathrm{~Hz}$ and vertical - $1075 \mathrm{~Hz}$.

But the foil protection system has a number of disadvantages, including the use of a power supply unit with different values of voltages and polarity $(-9 ; 9$;
$18 \mathrm{~V}$ ), that complicates the supply system and the performance characteristics of the unit. The usage of electromechanical relays and incandescent lamps, which serve to indicate an emergency, increases its energy consumption. A significant drawback of the protection unit is the lack of rapid feedback with the sweep system at a frequency of $1075 \mathrm{~Hz}$ that reduces the reliability level of the accelerator protection system in emergency situations. The above disadvantages have defined the necessity to improve the protection system of accelerators of this type.

\section{ANALYSIS OF INDUSTRIAL ELECTRON ACCELERATORS PROTECTION SYSTEMS}

The analysis of scientific and technical literature carried out by us showed that the problem of improving the protection systems of ELV-1 series accelerators for today is paid not enough attention. In modern electron accelerators ELV-8 and subsequent series, this problem is partially solved.

In contemporary accelerators of type ELV the protection circuit is made on a chip-comparator voltage. In the case the output current of the deflection coil supply generator exceeds $10 \mathrm{~A}$ for the line coil and $2 \mathrm{~A}$ for the horizontal sweep coil, at the output of this comparator the voltage, that will switch the CMOS series chip trigger on, occurs. Then, the signal from the trigger enters the micrologic circuit, which includes three elements NOR. From the output of the chip, the signal is fed to the fast protection unit, which, in turn, disconnects the power supply of the primary winding of the accelerator high-voltage rectifier. From the same chip the voltage comes to a LED on the protection system triggering, signaling the occurring of an emergency [7].

Such a protection scheme is developed for modern accelerators of this type, and an attempt to integrate it with the sweep unit of the electron accelerator ELV-1 or with sweep unit of another manufacturer causes difficulties that reduces the boundaries of its application. One of the main reasons for the impossibility of protection units widespread usage in other devices is the lack of the system actuation ranges regulation. In addition, existing protection schemes are included into sweep unit 
as a part of them, but are not performed by individual modules, making it difficult to diagnose and repair them.

In connection with the above-mentioned shortcomings of the protection systems of industrial ELV-1 series electron accelerators and the protection systems of the same type modern accelerators, it was necessary to develop more advanced protection system that would satisfy modern technical requirements, which are demanded to objects of this type equipment.

Nowadays among electron accelerators direct current DLS accelerators of the ELV-1 series are actively being used [8].

The main technical characteristics of the accelerator are presented in Table 1.

Table 1

Main technical characteristics of the ELV-1 series accelerators [9]

\begin{tabular}{|c|c|c|c|}
\hline Series & $\begin{array}{c}\text { Energy } \\
\text { range, MeV }\end{array}$ & $\begin{array}{c}\text { Power, } \\
\mathrm{kW}\end{array}$ & $\begin{array}{c}\text { Max. beam } \\
\text { current, } \mathrm{MA}\end{array}$ \\
\hline ELV-1 & $0.4 \ldots 0.8$ & 25 & 40 \\
\hline
\end{tabular}

In this series of accelerators, an electron beam with a diameter of about $8 \mathrm{~mm}$ passes an accelerating tube and the magnetic field formed by the deviation system coils (Fig. 1).

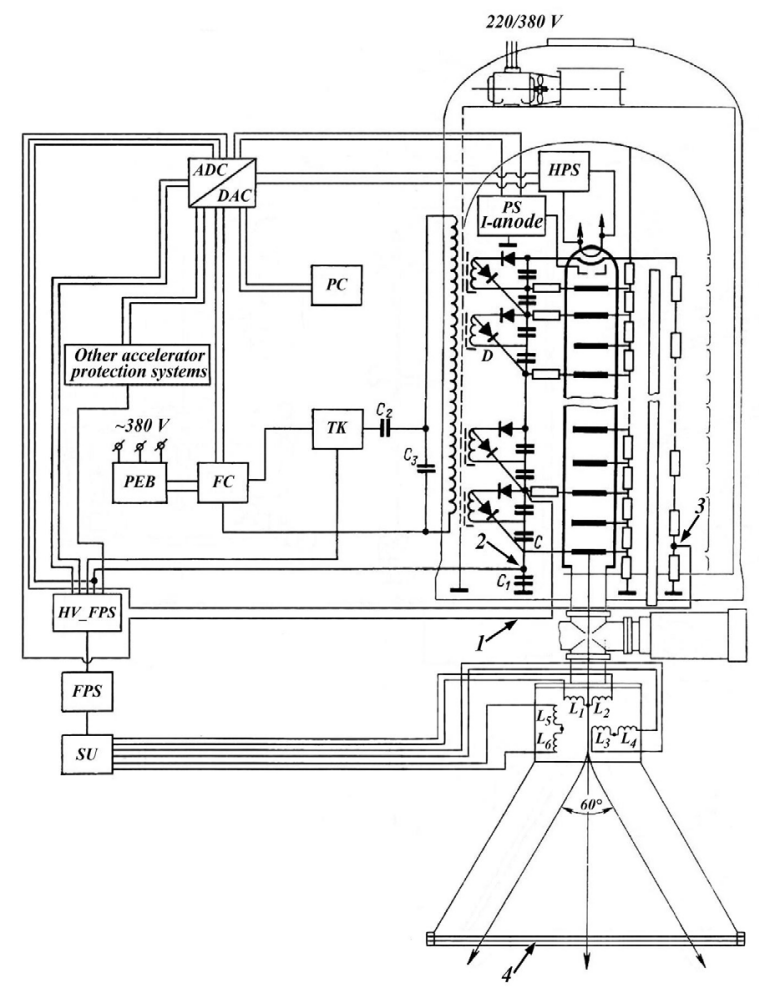

Fig. 1. Simplified functional diagram of the accelerator: SU - Scanner unit; FPS - foil protection system; HV_FPS - Fast protection system at high voltage breakdown; PEB - Power electric box; FC - Frequency converter; TK-Thyristor key; PC-Personal computer; PS I-anode-Power supply of the first anode; HPS - Heater Power supply;

ADC/DAC-Analog to digital converter/Digital to analog converter; 4 - titanium foil

The coils are powered by an external generator SU with a saw formed voltage. The electronic beam scans the titanium foil at a size of $75 \times 980 \mathrm{~mm}$ and a thickness of $50 \mu \mathrm{m}$ (see Fig. 1). The electrons scattering on the foil causes its heating. For the beam which current is equal to $30 \mathrm{~mA}$, loss on the scattering reaches $1500 \mathrm{~W}$.

For released heat energy rejection, it is used a blowoff by compressed air, which is pushed out the cooler gap, as shown in Fig. 2. Table 2 gives the basic technical characteristics of the beam deviation system and the accelerator output window.

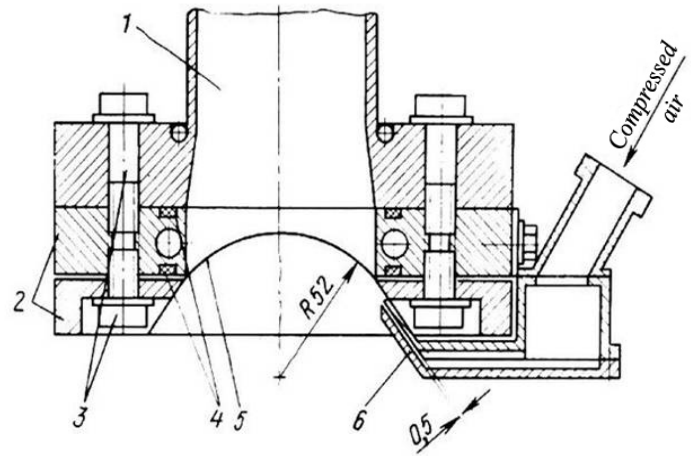

Fig. 2. Physical configuration of the accelerator outlet window in the section [4]:

1 -socket; 2 -frames; 3 -bolts; 4 -seals; 5 -titanium foil; 6 -cooler

Table 2

The system basic technical characteristics of a beam deflection and an outlet window [8]

\begin{tabular}{|l|c|}
\hline Line sweep deflection corner, deg. & \pm 30 \\
\hline $\begin{array}{l}\text { Scan Frequency, } \mathrm{Hz} \\
\text { - line: } \\
\text { - horizontal: }\end{array}$ & 50 \\
\hline $\begin{array}{l}\text { Irregularity of the beam current density } \\
\text { along the outlet window length, \% }\end{array}$ & \pm 1075 \\
\hline $\begin{array}{l}\text { Minimum pressure of compressed air at } \\
\text { the inlet to the cooler, } \mathrm{kgs} / \mathrm{cm}^{2}\end{array}$ & 0.5 \\
\hline
\end{tabular}

In the event of the line sweep operation disturbance, namely an interruption or short circuit in coils, electrical wires, and in the case of the similar emergency situations occurrence in the horizontal sweep coils, it is necessary to have a reliable foil protection system from burning by an electrons beam. Particular attention has to be paid to the case when the current, which passes through the line coil of deviation, disappears. Under these conditions, the energy of the electron flux is concentrated on a minor foil surface. The air flow in this case will not be enough to cool the titanium foil of the outlet window that leads to an emergency - its burning.

Since industrial accelerators operate almost continuously, the protection system must be sufficiently reliable and, in the event of a malfunction, available for on-line diagnostics and repair.

\section{RESULTS AND DISCUSSIONS}

Taking into account all of the above factors, we have carried out work on the development of the improved outlet window foil protection system by the current of line and horizontal scan coils of the electron beam deviation system. The physical configuration of the protection system module proposed by us is illustrated in Fig. 
3. A simplified functional diagram of the accelerator is presented in Fig. 1. The functional diagram of the protection system module developed by us is shown in Fig. 4.
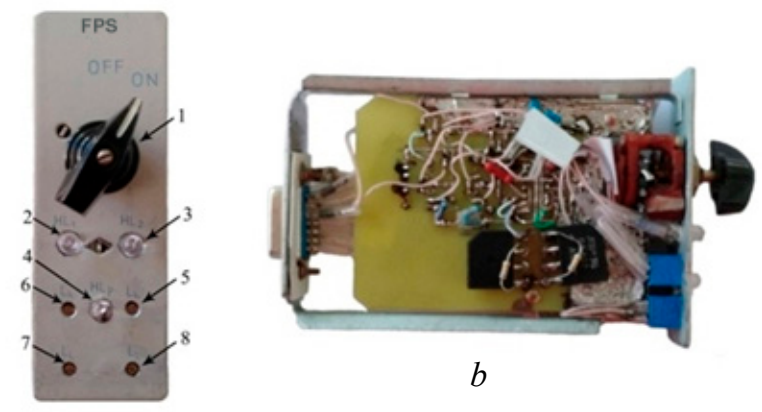

$a$

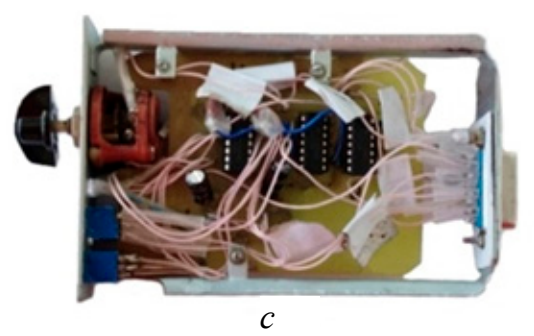

Fig. 3. Exterior of the protection system module:

a) front view; b), c) side view: 1 - switch;

2 - indicators of the 1-st channel emergency

situation; 3 - indicator of the 2-nd channel emergency

situation of; 4 -power indicator; 5 - the regulator

of the upper boundary of the 2-nd channel protection actuation; 6-regulator of the upper boundary of the 1-st channel protection actuation; 7 -indicator of the lower boundary of the 1-st channel actuation; 8 - indicator of the lower boundary of the 2-nd channel actuation

As can be seen from Fig. 3, the system has the form of a module with the overall dimensions $130 \times 82 \times 30 \mathrm{~mm}$, a printed circuit board $(\mathrm{PCB})-$ with dimensions of $97 \times 70 \mathrm{~mm}$.

One of has designed construction advantages is to make it as a separate module, as well as the installation of chips in a DIP type panel on the PCB. This approach simplifies replacing the module itself with a similar one, in the event of a malfunction and allows promptly replacing the main integrated circuits that shortens the time required for system repair.

On the front of the module, the power switch and the emergency situations indicators on the sweeps of the first channel with a frequency of $1075 \mathrm{~Hz}$ Channel-1 and the second channel with a frequency of $50 \mathrm{~Hz}$ Channel-2 (see Figs. 3,a, 4) and a power supply connection indicator have been output. The panel shows the axis of precision resistors for the setting the upper and lower thresholds of system actuation for 1 and 2 channels.

In our design, we used the standard scans unit (Gen1) to supply the power to the deflection system (DS) for electron accelerators ELV-1 proposed by the manufacturer (see Fig. 4).

The sweeps unit outputs X5/A5 and X5/B1 are supplied the voltage of the sawed form with a frequency of $1075 \mathrm{~Hz}$ to frame coils L5, L6, which are connected in series (see Figs. 4, 1). The electron beam deflection relative to the transverse direction is accomplished by adding a constant voltage component. The coils L5, L6 of the system deflect the electrons beam and scan it in transverse direction along the foil of the outlet window.

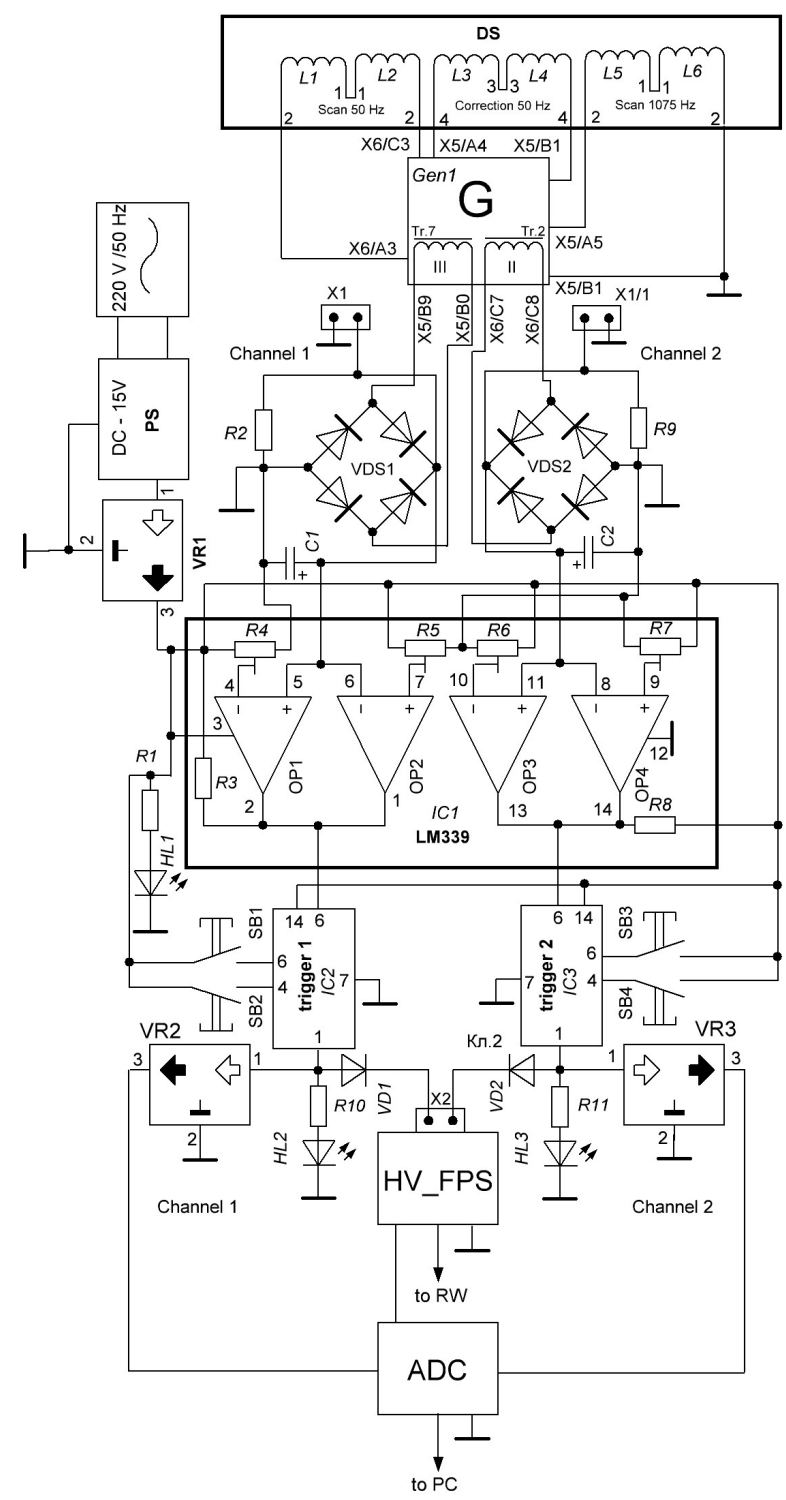

Parameters of electronic components:

VDS1, VDS2 - RS207

VD1, VD2 -1N4007

IC2, IC3-CD4013BE

VR2,VR3 - L7805

VR1 - L7812

R4-R7-200K

$\mathrm{R} 3, \mathrm{R} 8-2.2 \mathrm{~K}$

Fig. 4. Functional scheme of the protection system

From outputs X6/C3, X6/A3 of the sweep unit (see Gen1, Fig. 4) also a supply sawed-form voltage with a frequency of $50 \mathrm{~Hz}$ is transferred to the line coils of the deviation system L1, L2, which are connected in series. DS coils are intended to scan an electron beam in a longitudinal direction relative to the accelerator outlet window. Separate coils L3, L4 connected in series (see Figs. 4,1$)$ deflect the electrons beam from a longitudinal direction by adding a constant component of the voltage.

Consider the principle the operation of the system we developed on the case study of the first channel (the 
scan at a frequency of $1075 \mathrm{~Hz}$ ). The second channel at the sweep of $50 \mathrm{~Hz}$ works the same way (see Fig. 4). The transformer $\operatorname{Tr} 7$ in the scan unit Gen1 is connected in series by the primary winding with the L5, L6 frame coils. In the case a breakage in coils L5, L6 or in the circuits of their supply, the current on the Tr7 transformer primary winding drops to almost zero. As a result, the voltage on the transformer $\operatorname{Tr} 7$ winding III decreases. In the normal operating mode of the frame coil, the voltage from the transformer $\operatorname{Tr} 7$ winding III is transferred to the diode bridge of the first channel Channel-1 VDS 1. The rectified voltage is smoothed by a capacitor $\mathrm{C} 1$ of capacitance $0.48 \mu \mathrm{F}$ and enters the input of the first channel of the comparator IC1. Resistor R1 with $560 \mathrm{k} \Omega$ impedance serves to discharge capacitor $\mathrm{C} 1$. The upper resistance value (from $1.4 \mathrm{~V}$ and above) is set by resistor R5 and the lower (from 1.4 to $0 \mathrm{~V})$ resistance value of the first channel protection system actuation is set by resistor $\mathrm{R} 4$. The resistance values' setting is individual. Through resistor R3 the supply of the collector of the internal output transistor (not specified) of comparators OP1, OP2 of IC1 chip is carried. The protection system regulation for two reference values is one of the advantages, that distinguishes it from existing protection schemes. This solution significantly extends the possibilities of this module application and provides the ability to adjust it under a specific sweep unit.

In the event of an emergency (in the coils L5, L6) the voltage on the transformer Tr7 winding III decreases. When the voltage reaches the set upper reference value, the voltage of $12 \mathrm{~V}$ arises at the output of the comparators OP1, OP2 (outputs 2,1) and is applied to the trigger input (6-th output) IC2. After that the trigger IC2 pulls in the stable operating mode and at its output (1-st output) there will be a voltage of $12 \mathrm{~V}$. The LED HL2, connected through a resistor R10 which limits a current, signals on the state of emergency ("the accident at scanning $1075 \mathrm{~Hz}$ "). The fast protection system at high-voltage breakdown (HV-FPS) triggers through diode VD1 and disconnects power from the accelerator high voltage rectifier primary winding (Rectifier winding, RW) (see Figs. 1, 4). The time off of the accelerator rectifier by this HV-FPS protection system is regulated by the technical documentation and is no more than $1 / 2$ of the rectifier primary winding power supply period. Thus, for the frequency of the converter $v=400 \mathrm{~Hz}$, the half-period is: $\mathrm{T}_{1 / 2}=1 / \mathrm{v} \cdot 1 / 2=1.25 \cdot 10^{-3} \mathrm{~s}$.

Then, from the unit HV-FPS it is applied a signal on the system actuation to an analog-to-digital converter (ADC), which is assembled on the basis of the 8-bit microcontroller Atmega 2560 (see Figs. 1, 4). Implementation namely such a microcontroller series is given ground the fact that it also includes a digital to analog converter (DAC) module, that allowed us not only to handle and record signals from the main systems and accelerator nodes, but also to operate them.

Due to the ADC/DAC unit, it is possible to measure and control the following parameters of the accelerator nodes, which are shown in Fig. 1: at point 1 - the voltage at the section is measured; at point 2 - the beam current strength is measured; at point 3 - the beam energy is measured; on the HPS unit the heater power value is sets and, due to the ADC/DAC feedback, the cathode heater current and voltage are measured; on the block PS I-anode the voltage on the first anode is set and, due to the feedback of the ADC/DAC, the current and voltage on the first anode are measured, that allows the beam power to be regulated. The accelerating voltage for the electron beam energy controlling is set by the $\mathrm{ADC} / \mathrm{DAC}$ unit due to the connection to the $\mathrm{PC}$ frequency converter (see Fig. 1).

The exit from an emergency mode is carried out by pressing the button SB2 only in case of troubleshooting in the coils L5, L6 or other related circuits. An attempt to press the button in the emergency mode will not cause anything, the reset won't actuate. The trigger IC2 exactness checking can be performed quickly by the button SB1. In the case the button is closed, the trigger will enter a steady state, the LED HL2 will turn on and the accelerator will turn off. At output IC2, the integral stabilizer VR2 will generate a signal voltage (3-rd output) $\mathrm{U}=5 \mathrm{~V}$, which continues to enter the analog-todigital converter ADC, indicating that the $1075 \mathrm{~Hz}$ sweep protection system is triggered. An analogue-todigital converter captures signals from the integral stabilizer VR2 and the HV-FPS fast protection system and sends them in discrete form to a personal computer (PC) on which screen the operator receives information about the protection system actuation (see Figs. 1, 4)

The outputs X1 and X1/1 (see Fig. 4) are intended for connection to the channels (Channel-1, Channel-2) of the electron beam sweeps and correction unit, manufactured by LLC "Research and production enterprise Mikont". The signal from the emergency exits of the series blocks has a permanent shape and does not require straightening, so it comes immediately to the output of diode bridges VDS1, VDS2. In the sweeps unit it is provided the ability to turn off the power supply of the deviation scan coils in the event of the signals appearance on emergency outputs that makes it impossible to continue the rejection coils supply. This allows protecting not only the outlet window foil, but also the key transistors of the sweep block. The system is powered by a power supply (PS) unit at a voltage of $15 \mathrm{~V}$ and stabilized by an integral stabilizer VR1 of series L7812, at the output of which we get a voltage of $12 \mathrm{~V}$ (see Fig. 4). An indication of supply voltage application of $12 \mathrm{~V}$ is carried out by the LED HL1.

The proposed protection system was tested during one year on the accelerator series ELV-1 in LLC "Azov Cable Company". During the system service there were no deficiencies to find out in the operation. This gives grounds for arguing that it can be used as part of industrial electron accelerators of the suggested series.

Thus, the usage of the offered protection system allows to shut down the accelerator power fast and to protect the foil from its burning by an electron beam timely.

\section{CONCLUSIONS}

The following main results have been obtained during the work:

1. The advanced protection system of the electrons accelerator ELV-1 allowed for a time no more than $1.25 \cdot 10^{-3} \mathrm{~s}$ to disconnect the power of the primary wind- 
ing of a high-voltage rectifier, preventing the accelerator outlet window foil burning, both for currents of frequency $50 \mathrm{~Hz}$, and for currents of frequency $1075 \mathrm{~Hz}$.

2. The use of an analog-to-digital converter, allows you to connect a personal computer through the USBinterface to monitor the protection system operation.

3 . Realization of the opportunity of the regulating the protection system operation range on two channels and the organization of inputs $\mathrm{X} 1, \mathrm{X} 1 / 1$ allowed to connect the electron beam sweeps and correction unit of LLC "Research and production enterprise Mikont", as well as similar blocks of other modern manufacturers to the accelerator.

4. Modular implementation of the protection unit, the usage of a unipolar voltage supply and the refuse of electromagnetic relays and the replacement of incandescent lamps on the LEDs allowed reducing the size and the consumption power of the system.

\section{PERSPECTIVES FOR FURTHER RESEARCH}

Further research and improvement of the protection system may be aimed at the development of PC software for effective control and operation of protection systems in an automatic mode without the active participation of the operator.

\section{ACKNOWLEDGEMENTS}

Finally, the authors express their gratitude to the Director of LLC "Azov Cable Company" V.V. Kara, Chief Engineer I.V. Dubiaga and Head of the charged particles accelerator section V.G. Radchenko for the help in working to improve the electron accelerators as part of the writing of this work.

\section{REFERENCES}

1. Robert W. Hamm. Industrial Accelerators // Reviews of Accelerator Science and Technology. 2008, v. 1, p. 174-175.
2. V.L. Auslender. 5...10 MeV Industrial High Power Electron Accelerators // Proc. Int. Linac Conf. Gyeongju, Korea, Aug. 19-23, 2002, p. 284-288.

3. M.R. Cleland. Industrial applications of Electron Accelerators // CERN Accelerator School, Zeegse, The Netherlands, May 24 - June 2, 2005, Available at: https://cds.cern.ch/record/1005393/files/p383.pdf (accessed 12 September 2018).

4. N. Kuksanov, R. Salimov, P. Nemytov, S. Fadeev, and P. Nemytov. DC ELV Accelerators: Development and Application // ICARST 2017 International Conference on Applications of Radiation Science and Technology, 24-28 April 2017, Vienna, Austria, p. 151 .

5. A.A. Brjazgin, N.K. Kuksanov, R.A. Salimov. Uskoriteli jelektronov dlja promyshlennogo primenenija razrabotannye v IJaF im. Budkera SO RAN // Uspehi fizicheskih nauk. 2018, v. 188, № 6, p. 672 685. https://doi.org/10.3367/UFNe.2018.03. 038344 (in Russian).

6. A.V. Bublej, M.Je. Vejs, N.K. Kuksanov, et al. Usovershenstvovannyj promyshlennyj uskoritel' jelektronov dlja obluchenija kabel'noj izoljacii // Nauka i tehnika. 2004, № 4 (287), p. 16-19 (in Russian).

7. Technicheskoe opisanie uskoritelei ELV-8. Schemy electricheskie printsipial'nye blokov upravleniya. Budker Institut Yadernoy Physiki SO RAN Novosibirsk. 2016, p 20 (in Russian).

8. G.I. Budker, V.A. Gaponov, B.M. Korabel'nikov, et al. Uskoritel' jelektronov dlja promyshlennogo pol'zovanija // Atomnaja jenergija. 1976, v. 40, № 3, p. 216-219 (in Russian).

9. P.I. Nemytov. Sistemy pitanija i upravlenija serii vysokovol'tnyh promyshlennyh uskoritelej jelektronov s moshhnost'ju sotni kilovatt. Diss. dokt. tehn. Nauk. Novosibirsk, 2010, p. 13-17 (in Russian).

Article received 06.05.2019

\section{УСОВЕРШЕНСТВОВАННАЯ СИСТЕМА ЗАЩИТЫ ОТ ПРОЖОГА ФОЛЬГИ ВЫПУСКНОГО ОКНА ПРОМЫШЛЕННЫХ УСКОРИТЕЛЕЙ ЭЛЕКТРОНОВ}

\section{С.О. Бандуров, Р.С. Ложкин, Г.А. Шиикин}

Приведены результаты анализа недостатков системы защиты промышленных ускорителей электронов при возникновении аварийных ситуаций и предложены способы ее усовершенствования. Описан принцип работы функциональной схемы системы защиты и ее основные характеристики. Предложенная система защиты по току обмоток строчной и кадровой разверток может быть применена в промышленных ускорителях серии ЭЛВ-1.

\section{УДОСКОНАЛЕНА СИСТЕМА ЗАХИСТУ ВІД ПРОПАЛЮВАННЯ ФОЛЬГИ ВИПУСКНОГО ВІКНА ПРОМИСЛОВИХ ПРИСКОРЮВАЧІВ ЕЛЕКТРОНІВ}

\section{С.О. Бандуров, Р.С. Ложкін, Г.О. Шишкін}

Наведено результати аналізу недоліків системи захисту промислових прискорювачів електронів при виникненні аварійних ситуацій та запропоновано засоби їі вдосконалення. Описано принцип роботи функціональної схеми системи захисту та її основні характеристики. Запропонована удосконалена система захисту за струмом обмоток рядкової та кадрової розгорток може бути застосована в промислових прискорювачах серії ЕЛВ-1. 